\title{
PENGEMBANGAN BUKU SAKU TUMBUHAN PAKU BERDASARKAN IDENTIFIKASI PTERIDOPHYTA DI SEKITAR DANAU DENDAM KOTA BENGKULU
}

\author{
Hanum Slavia ${ }^{*}$, Kasrina ${ }^{1}$, Irwandi Ansori ${ }^{1}$ \\ ${ }^{1}$ Program Studi Pendidikan Biologi, Fakultas Keguruan dan Ilmu Pendidikan, Universitas Bengkulu \\ Email: hanumslavia123@gmail.com
}

\begin{abstract}
ABSTRAK
Penelitian ini bertujuan untuk membuat buku saku tumbuhan paku berdasarkan hasil identifikasi keanekaragaman jenis tumbuhan paku di sekitar Danau Dendam Kota Bengkulu. Jenis penelitian adalah penelitian dan pengembangan ( $R \& D$ ) dengan tahapan (1) Identifikasi potensi dan masalah, (2) Pengumpulan informasi, (3) Desain produk, (4) Validasi produk, (5) Revisi desain, (6) Uji keterbacaan, dan (7) Revisi produk. Data penelitian dianalisis secara deskriptif. Berdasarkan hasil identifikasi diperoleh 8 spesies tumbuhan paku yang tergabung dalam tujuh genus, empat famili dan tiga ordo. Hasil keragaman tumbuhan paku yang diperoleh kemudian dijadikan bahan ajar berupa buku saku tumbuhan paku. Validasi uji kelayakan buku saku dilakukan oleh tiga dosen dan 1 orang guru Biologi. Hasil validasi menunjukkan buku saku termasuk dalam kategori "Sangat Baik" dengan persentase keidealan keseluruhan sebesar 88.25\%. Hasil respon dari 20 siswa terhadap buku saku termasuk dalam "Sangat Baik" dengan persentase keidealan keseluruhan yaitu $91.37 \%$. Kata Kunci: Penelitian dan Pengembangan, Tumbuhan Paku, Buku Saku
\end{abstract}

\begin{abstract}
This research is Research and Development research (R\&D). The purpose of this research To make Biology pocket book based on the exploration result of Pteridophyta species and to describe elegibility. Steps of this research are: (1) Problem and Potensial (2) Collecting data (3) Product Design (4) Product Validation (5) Product Revision, (6) Validity, and (7) Product Revision. The data has been analyzed by descriptive method. This research found three ordo, four families, seven genus and eight spesies of Pteridophyta. Validation test of teaching material has been proved by three examiners and the result is "Very Good" with an ideal percentage $88.25 \%$. The response of 20 students about the pocket book is "Very Good" with an ideal percentage $91.37 \%$. The design of the pocket book based on validity and reliability consist of: 1. Cover 2. 3 . Title, KI, KD, Teaching Purpose 4. Table content 5. Background parts consist of research location, general material of Pteridophyta, Pteridophyta life cycle, Pteridophyta grouping, Pteridophyta determination 6. Content consist of identification result and Pteridophyta description; classification, description, and Pteridophyta picture 7. Closing part consist of Pteridophyta rule, glossarium, exercise and the key, and references. The Pocket Book expressed "WORTH" is used in Biology learning on Plater submater Pteridophyta material which is proven by validation result by lecturer of material expert, Biology teacher and student's response to this nail plant pocket book.
\end{abstract}

Keywords: Research and Development, Pteridophyta, Pocket Book 


\section{PENDAHULUAN}

Penerapan kurikulum 2013 menuntut guru meningkatkan kualitas pembelajaran secara aktif dan inovatif. Salah satu upaya peningkatan kualitas pembelajaran adalah dengan cara mengembangkan berbagai bahan ajar. Bahan ajar yang bervariasi dapat menciptakan ragam pilihan yang dapat disesuaikan dengan kebutuhan guru dan siswa. Pemilihan bahan ajar secara tepat oleh guru akan menarik minat siswa, sehingga siswa akan termotivasi untuk belajar secara mandiri. Pemilihan bahan ajar yang tepat, mudah dipahami dan dipelajari, berisi materi yang sesuai dengan kurikulum, serta melibatkan peran aktif siswa, akan mendukung tercapainya tujuan pembelajaran (Yuliani, 2015).

Salah satu metode untuk meningkatkan kualitas pembelajaran adalah dengan memberikan pengalaman belajar secara langsung (real experience) kepada peserta didik. Pembelajaran secara langsung dapat terjadi ketika guru memberikan kesempatan belajar melalui aneka bahan ajar dari sumber belajar lingkungan. Metode ini dapat merangsang peserta didik untuk berpikir ilmiah dan mampu memecahkan masalah dalam kehidupan sehari-hari sesuai dengan tuntutan pembelajaran kurikulum 2013 (Kemendikbud, 2014).

Berdasarakan hasil wawancara terhadap guru Biologi SMAN 4 Kota Bengkulu diperoleh informasi bahwa guru masih menemukan kesulitan dalam pembuatan bahan ajar. Bahan ajar yang digunakan berupa buku paket dari Departemen Pendidikan Nasional Pusat dan LKS yang berasal dari penerbit. Buku paket yang berukuran besar ini kurang praktis untuk pelaksanaan kegiatan pembelajaran di luar ruangan kelas. Keterbatasan bahan ajar yang digunakan mengakibatkan kegiatan pembelajaran dan pengetahuan yang diperoleh siswa menjadi tidak optimal. Berdasarkan permasalahan ini, peneliti melakukan observasi tumbuhan paku (Pteridopyhta) sekitar sekolah untuk pembuatan bahan ajar yang lebih menarik dan inovatif. Lingkungan sekitar SMAN 4 dengan keragaman Pteridophyta yang tinggi adalah kawasan Danau Dendam Tak Sudah. Keanekaragaman tumbuhan paku yang terdapat di sekitar Danau Dendam Tak
Sudah dapat dikembangkan sebagai bahan ajar pada materi Plantae kelas $X$.

Model bahan ajar yang dibuat dalam penelitian ini adalah buku saku biologi. Buku saku memiliki keunggulan berupa lebih praktis untuk dibawa karena berukuran kecil (Kamus Besar Bahasa Indonesia, 2009). Buku Saku juga dapat didesain dengan tampilan dan warna yang menarik, disertai uraian bacaan yang pendek. Buku Saku merupakan alternatif untuk buku paket yang cenderung berukuran besar dan kurang praktis untuk pembelajaran di luar kelas. Keberadaan buku saku diharapkan dapat memotivasi siswa untuk lebih aktif dalam mencari pengetahuan yang berasal dari lingkungan sekitar.

\section{METODE PENELITIAN}

Jenis penelitian ini adalah penelitian penelitian pengembangan (Research and Development/R\&D) Borg \& Gall (1983 dalam Sugiyono 2013). Langkah-langkah penelitian ini adalah sebegai berikut: (1). Identifikasi potensi dan masalah; (2). Pengumpulan informasi; (3). Desain produk; (4). Validasi produk; (5). Revisi produk; (6). Uji keterbacaan; dan (7). Revisi produk. Penelitian ini dilakukan pada bulan Maret hingga Mei 2017.

Sampel tumbuhan paku yang digunakan dalm penelitian ini dikoleksi dari kawasan Danau Dendam Tak Sudah Kota Bengkulu untuk kemudian diidentifikasi. Hasil identifikasi ini kemudian diaplikasikan dalam buku saku kelas $X$ MIPA 4 SMAN 4 kota Bengkulu. Teknik pengumpulan data dan pengembangan instrument yang digunakan dapat dilihat pada Tabel 1.

Tabel 1. Teknik Pengumpulan Data dan Instrumen

\begin{tabular}{lll}
\hline No & $\begin{array}{l}\text { Teknik } \\
\text { Pengumpulan } \\
\text { Data }\end{array}$ & $\begin{array}{l}\text { Instrumen yang } \\
\text { digunakan }\end{array}$ \\
\hline 1. & Observasi & $\begin{array}{l}\text { Lembar observasi } \\
\text { lapangan } \\
\text { Lembar validasi ahli } \\
\text { dan lembar respon } \\
\text { siswa } \\
\text { Buku, Jurnal, Artikel } \\
\text { dan hasil penelitian } \\
\text { yang terkait. }\end{array}$ \\
\hline
\end{tabular}


diperoleh dari hasil penelitian 2) Analisis data kelayakan buku saku dan Respon Siswa. Skor yang Teknik analisa data yang digunakan dalam didapat dari angket/lembar observasi dikonversi penelitian ini sebagai berikut 1) analisis Data Observasi Identifikasi Tumbuhan Paku Data yang ke skala empat dan kriteria kualitatif dengan mengacu pada Tabel 2 dan Tabel 3.

Tabel 2. Konversi Skor Ideal Menjadi Skala

\begin{tabular}{ccc}
\hline No & Rentang Skor Kualitatif & Kategori Kualitatif \\
\hline 1. & $X \geq X_{i}+1,8 S b_{i}$ & Sangat Baik \\
2. & $X_{i}+0,6 S b_{i}<X \leq X_{i}+1,8 S b_{i}$ & Baik \\
3. & $X_{i}-0,6 S b_{i}<X \leq X_{i}+0,6 S b_{i}$ & Cukup baik \\
4. & $X_{i}-1,8 S b_{i}<X \leq X_{i}-0,6 S b_{i}$ & Kurang baik \\
\hline
\end{tabular}

Tabel 3. Persentase Keidealan

\begin{tabular}{|c|c|c|}
\hline No & Rentang skor ideal (\%) & Kategori Kualitatif \\
\hline 1. & $\mathrm{X}>\frac{\mathrm{Xi+1,8 \textrm {Sbi }}}{\text { skor maks.ideal }} \times 100 \%$ & Sangat Baik \\
\hline 2. & $\frac{X i+0,6 \text { Sbi }}{\text { skor maks.ideal }} x 100 \%<X \leq \frac{X i+1,8 \text { Sbi }}{\text { skor maks.ideal }} x 100 \%$ & Baik \\
\hline 3. & $\frac{X i-0,6 \mathrm{Sbi}}{\text { skor maks.ideal }} \times 100 \%<\mathrm{X} \leq \frac{X i+0,6 \mathrm{Sbi}}{\text { skor maks.ideal }} \times 100 \%$ & Cukup Baik \\
\hline 4. & $\frac{X i-1,8 \text { Sbi }}{\text { skor maks.ideal }} x 100 \%<\mathrm{X} \leq \frac{X i-0,6 \text { Sbi }}{\text { skor maks.ideal }} \times 100 \%$ & Kurang Baik \\
\hline
\end{tabular}

Keterangan :

$\mathrm{X} \quad=$ skor yang dicapai

$\mathrm{Xi} \quad=$ rerata skor ideal

Sbi $=\frac{1}{6}$ (skor maksimal ideal - skor minimal ideal)

Skor minimal ideal $=\sum$ butir kriteria $\mathrm{x}$ skor tertinggi Skor minimal ideal $\quad=\sum$ butir kriteria $\mathrm{x}$ skor terendah

(Widoyoko, 2009)

\section{HASIL DAN PEMBAHASAN}

Jenis-Jenis Tumbuhan Paku di Kawasan Danau Dendam Tak Sudah Kota Bengkulu

Penelitian ini menemukan delapan spesies tumbuhan paku di kawasan Danau Dendam Tak Sudah Kota Bengkulu. Kedelapan spesies ini tergabung dalam tujuh genus, empat famili, dan tiga ordo. Kelembaban udara di sekitar danau sebesar $52 \%$ dengan suhu udara berkisar $29^{\circ}$. Kawasan Danau Dendam memiliki pohonpohon yang cukup besar sehingga keragaman tumbuhan paku yang dijumpai masih cukup tinggi. Hal ini sejalan dengan pendapat Soesilo (1986) yang

menyatakan bahwa tumbuhan paku terutama dijumpai di tempat-tempat yang lembab daerah tropis maupun subtropis.

Berdasarkan hasil studi keanekaragaman jenis tumbuhan paku yang ada di kawasan sekitar Danau Dendam memiliki karakteristik yang bervariasi antar jenisnya. Hal ini dapat di lihat dari rimpang, ciri daun seperti tipe daun, bentuk, ujung, dan tepi daun, serta sorus. Tumbuhan paku yang rimpangnya menjalar dapat ditemukan 6 jenis yaitu Gleichenia linearis, Lygodium microphyllum, Lygodium circinnatum, Davallia denticulata, Pyrrosia lanceolata dan Phymatosorus scolopendria. Sedangkan yang rimpangnya tegak ditemukan 2 jenis yaitu Neprolephis exalta dan Cyclosorus maemonensis. Tipe daun tumbuhan paku yang di temukan di kawasan sekitar Danau Dendam ada yang majemuk dan ada juga yang tunggal. 


\section{Produk Buku Saku}

Desain buku saku yang telah dikembangkan meliputi: 1). Sampul depan (Gambar 1); 2). Kata pengantar; 3). Judul, KI, KD, Tujuan Pembelajaran; 4). Daftar isi 5). Bagian pendahuluan meliputi penjelasan tentang lokasi penelitian, dan ciri umum (Gambar 2 dan $3)$, siklus hidup, pengelompokkan, dan kunci determinasi tumbuhan paku; 6). Bagian isi terdiri dari hasil identifikasi, deskripsi dan foto jenis-jenis paku yang ditemukan; 7). Bagian penutup terdiri dari peranan tumbuhan paku, daftar istilah, latihan soal, kunci jawaban dan daftar pustaka. Ukuran buku saku yang dikembangkan adalah $15 \times 12 \mathrm{~cm}$ dengan huruf Berlin Sans FB berukuran 12. Adapun desain sampul depan dapat dilihat pada Gambar 1. Untuk tampilan isi dari buku saku dapat dilihat pada Gambar 2

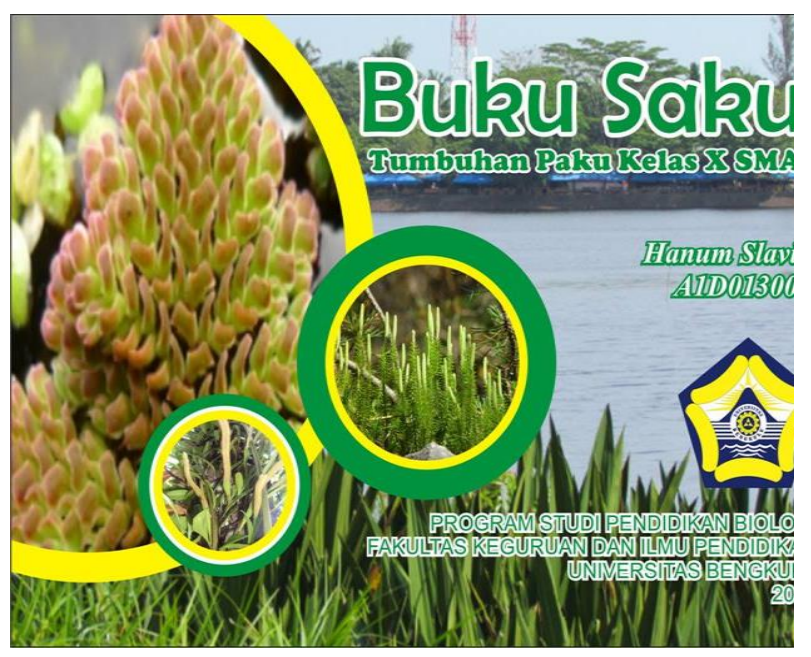

Gambar 1. Desain sampul depan buku saku tumbuhan paku di kawasan Danau Dendam Tak Sudah Kota Bengkulu

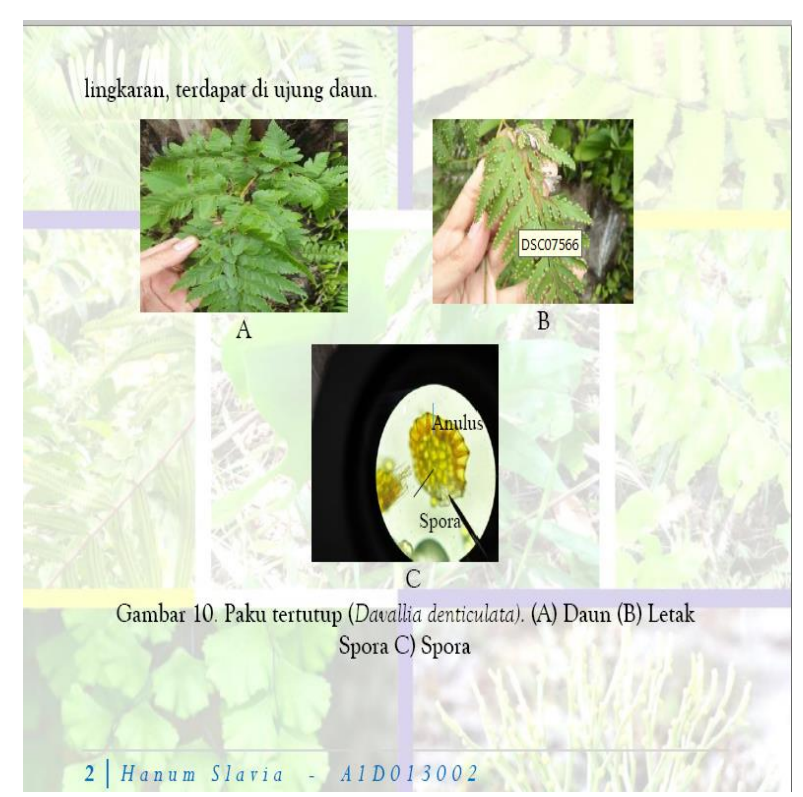

Gambar 2. Ciri umum tumbuhan paku dalam buku saku tumbuhan paku di kawasan Danau Dendam Tak Sudah Kota Bengkulu

Buku saku selanjutnya divalidasi sebelum melalui tahap uji keterbacaan. Validasi yang dilakukan mengacu pada Peraturan Pemerintah Nomor 32 tahun 2013 dengan empat aspek validasi utama yaitu kelayakan isi, kebahasaan, penyajian, dan kegrafikaan. Penilaian buku teks pelajaran mengacu pada instrumen Penilaian Buku Teks Pelajaran dari Badan Standar Nasional Pendidikan (BSNP, 2014) sebagai berikut:

1) Kelayakan Isi. Penilaian kelayakan isi buku saku dilihat dari dimensi sikap spiritual dan sosial, dimensi pengetahuan, dan dimensi keterampilan sesuai dengan kurikulum 2013.

2) Kelayakan Kebahasaan. Penilaian kelayakan kebahasaan buku saku dilihat dari kesesuaian dengan perkembangan siswa, keterbacaan, kemampuan memotivasi, kelugasan, koherensi dan keruntutan alur pikir, kesesuaian dengan kaidah Bahasa Indonesia, serta penggunaan istilah dan simbol.

3) Kelayakan Penyajian. Penilaian kelayakan penyajian buku saku dilihat dari teknik penyajian, pendukung materi, penyajian pembelajaran, dan kelengkapan penyajian.

4) Kelayakan Kegrafikaan. Penilaian kelayakan kegrafikan buku saku dilihat dari 
ukuran buku, desain kulit buku, dan desain isi buku.

Berdasarkan hasil peneltian diketahui bahwa nilai rata-rata kevalidan buku saku yang dibuat secara keseluruhan adalah 35.3 dengan persentase kevalidan $88.25 \%$ (Tabel 4). Berdasarkan nilai tersebut, buku saku ini termasuk dalam kategori sangat valid. Hal ini berarti bahwa keseluruhan komponen yang disajikan buku saku layak untuk digunakan sebagai bahan ajar dalam proses belajar mengajar, baik dari segi desain/struktur maupun dari segi isi materi.

Tabel 4. Hasil Validasi Dosen Ahli dan Guru Biologi Terhadap Buku Saku Tumbuhan Paku di Kawasan Danau Dendam Tak Sudah Kota Bengkulu

\begin{tabular}{|c|c|c|c|}
\hline Aspek & $\begin{array}{l}\text { Nilai rata- } \\
\text { rata }(X)\end{array}$ & $\begin{array}{l}\text { Persen } \\
\text { tase } \\
\text { kevali } \\
\text { dan } \\
(\%)\end{array}$ & Kriteria \\
\hline $\begin{array}{l}\text { Kelayakan } \\
\text { Materi/Isi }\end{array}$ & 11.3 & 94.4 & $\begin{array}{l}\text { Sangat } \\
\text { Baik }\end{array}$ \\
\hline $\begin{array}{l}\text { Penyajian } \\
\text { Materi/Isi } \\
\text { Bahasa, }\end{array}$ & 9.6 & 80.5 & $\begin{array}{l}\text { Sangat } \\
\text { Baik }\end{array}$ \\
\hline $\begin{array}{l}\text { Gambar } \\
\text { dan Foto }\end{array}$ & 6 & 75 & Baik \\
\hline Desain & 6.6 & 82.5 & Baik \\
\hline $\begin{array}{l}\text { Jumlah } \\
\text { Keseluruha } \\
\mathrm{n}\end{array}$ & 35.3 & 88.25 & $\begin{array}{l}\text { Sangat } \\
\text { Baik }\end{array}$ \\
\hline
\end{tabular}

Setelah buku dinyatakan layak digunakan dalam proses pembelajaran, selanjutnya dilakukan uji keterbacaan oleh siswa/i X MIPA 2 SMAN 4 kota Bengkulu. Dalam uji keterbacaan ini, siswa memberikan respon terhadap buku saku yang sudah dibuat. Respon siswa terhadap uji keterbacaan terhadap buku saku yang dibuat menunjukkan hasil yang sangat bagus yaitu sebesar 94\%. Sejalan dengan pendapat Khabibah (tahun??? dalam Yamasari 2010), jika persentase respon siswa di atas $85 \%$ maka terhadap buku saku tergolong sangat positif.

\section{PENUTUP}

Simpulan

Berdasarkan hasil analisis data dan pembahasan yang telah dilakukan, dapat disimpulkan bahwa:

a. Terdapat delapan spesies tumbuhan paku di sekitar Danau Dendam Tak Sudah Kota Bengkulu yaitu Davalia denticulata, Phymatosorus scolopendria, Pyrrosia lanceolata, Cyclosorus maemonensis, Lygodium microphyllum, Lygodium circinnatum, Gleichenia linearis dan Neprolephis exalta. Kedelapan jenis tumbuhan paku ini tergolong dalam tujuh genus, empat family dan tiga ordo.

b. Sistematik buku saku yang telah dikembangkan adalah: 1). Sampul depan buku saku atau cover; 2 ). Kata pengantar; 3). Judul, KI, KD, Tujuan Pembelajaran; 4). Daftar isi 5). Bagian pendahuluan; 6). Bagian isi; dan 7). Bagian penutup. Buku saku ini dinyatakan "LAYAK" digunakan dalam pembelajaran Biologi pada materi plantae submateri Pteridophyta.

\section{Saran}

Buku saku ini dapat dijadikan sebagai bahan penelitian lanjutan untuk memperbaiki proses pembelajaran di kelas.

\section{DAFTAR PUSTAKA}

BKSDA. 2011. Danau Dendam Tak Sudah Kota Bengkulu.

(http://bksdabengkulu.org/konse rvasi-kawasan/ca-garalam/danaudendam/ Diakses 26 Januari 2017.

BSNP. 2014. Pedoman Penilaian. Jakarta: Departemen Pendidikan Nasional.

Kinho, Julianus. 2009. Mengenal Beberapa Jenis Tumbuhan Paku Di Kawasan Hutan Payahe Taman Nasional Aketajawe Lolobata Maluku Utara. Penerbit Balai Penelitian Kehutanan Manado.

Permendikbud, 2016. Peraturan Menteri Pendidikan Dan Kebudayaan Nomor 22 Tahun 2016 Tentang 
Standar Proses Pendidikan Dasar Dan Menengah. Jakarta: Kementrian Pendidikan Dan Kebudayaan.

Setyosari, Punaji. 2013. Metode Penelitian Pendidikan \& Pengembangan. Jakarta: Kencana Prawamedia Grup

Soesilo, dkk, 1986. Buku Materi Pokok BIOLOGI. Departemen Pendidikan dan Kebudayaan. Universitas Terbuka.

Sugiyono. 2013. Metode Penelitian Kuantitatif Kualitatif dan R\&D. Bandung: Alfabeta

Sumanto, 2014. Teori dan Aplikasi Metode Penelitian. Jakarta: PT. BUKU SERU
Tim Pengembang MKDP. 2013. Kurikulum dan Pembelajaran. Jakarta: Rajawali Pers

Tjitrosoepomo, Gembong. 1986. Taksonomi Tumbuhan. Yogyakarta: UGM press

Yamasari, Yuni. 2010. Pengembangan Media Pembelajaran Matematika Berbasis ICT yanag Berkualitas. Seminar Nasional Pascasarjana XITS. ISBN No. 979-5445-0270-1

Yuliani, Fahtria. 2015. Pengembangan Buku Saku Materi Pemanasan Global Untuk SMP. Jurusan Biologi Fakultas Matematika dan IImu Pengetahuan Alam. Universitas Negeri Semarang. 